\title{
MEMBANGUN KEPEMIMPINAN DALAM DIRI ANAK SEJAK USIA DINI
}

\author{
Widarman Waruwu \\ Sekolah Tinggi Agama Kristen Terpadu Pesat, Salatiga \\ Email: widarwaruwu99@gmail.com
}

\section{Abstract}

In building children's leadership, the main thing that needs to be considered/expected is to know the stages of growth and development of children from an early age. In building leadership in children, it is important for parents and teachers to know what to apply in children from an early age. In this study using library research methods / literature. The purpose of this study, so that parents and educators as well as readers know how to build leadership in children, the main growth and development of children that must be considered and what is applied to children according to their needs at that age. This writing was done with library research.

Keywords: leadership, early childhood seisk children

\begin{abstract}
Abstrak
Dalam membangun kepemimpinan anak, hal utama yang perlu di perhatikan/diharapkan yaitu mengetahui tahap pertumbuhan dan perkembangan anak sejak usia dini. Dalam membangun kepemimpinan dalam diri anak, penting bagi orang tua dan guru untuk mengetahui apa yang harus di terapkan dalam diri anak sejak dini. Dalam penelitian ini menggunakan metode penelitian kepustakaan/ literatur. Penelitian ini bertujuan untuk mendeskrisikan bagaimana membangun kepemimpinan dalam diri anak, pertumbuhan dan perkembangan anak yang utama yang harus diperhatikan diterapkan kepada anak sesuai kebutuhannya pada usia dini. Penulisan ini dilakukan dengan penelitian kepustakaan.
\end{abstract}

Kata kunci : Kepemimpinan, Anak sejak usia dini,

\section{PENDAHULUAN}

Kepemimpinan adalah pengaruh. Jika seseorang meningkatkan pengaruhnya dalam diri orang lain, mereka bisa memimpin dengan lebih efektif. ${ }^{1}$ Timotius juga berpendapat sama dengan John C.

\footnotetext{
1 John C. Maxwell, The 5 Leves of Leadership (surabaya, 2017), hal 2.
}

Maxwell mengatakan kepemimpinan adalah sebuah pengaruh, sedangkan pemimpin adalah seseorang yang memiliki pengaruh. $^{2}$ Kepemimpinan ini, dapat kita katakan bahwa kepemimpinan itu sendiri

\footnotetext{
${ }^{2} \mathrm{k}$. H Timotius, kepemimpinan dan kepengikutan teori dan perkembangannya. (Andi, Yogyakarta, 2016)hlm.
} 
adalah pengaruh yang diberikan oleh seseorang kepada orang lain. Namun berbicara tentang kepemimpinan ada dua bagian kepemimpinan yaitu, yang pertama adalah kepemimpinan atau seorang pemimpin yang membawah pengaruh yang baik atau positif, dan yang kedua adalah kepemimpinan atau seorang pemimpin yang membawah pengaruh yang tidak baik atau pengaruh yang negatif.

Tujuan dalam membangun kepemimpinan dalam diri anak supaya adanya nilai-nilai kepemimpinan dalam diri anak sejak dari kecil. Nilai-nilai kepemimpinan yang di harapkan adalah dimana anak memiliki karakter, perspektif, keberanian, kebaikan hati dan mempunyai integritas yang tinggi, juga anak mampu menjadi pemimpin yang sehat kelak setelah anak besar. Di mana pemimpin yang sehat adalah pemimpin yang bertumbuh dalam $5 \mathrm{C}$.

Prinsip dalam membangun kepemimpinan anak, supaya anak bisa mengenal dirinya sendiri, mengembangkan bakat anak sejak dari kecil, menemukan hasratnya, menghargai orang lain, melatih kegigihan anak sejak dari kecil supaya menciptakan keunggulan mutu yang lebih

\footnotetext{
${ }^{3}$ Dr. Tim Elmore and John C. Maxwell, Mengembangkan Talenta Kepemimpinan Dalam Anak Anda (Jakarta, 2002).

${ }^{4}$ TIM ANAK BERSINAR BANGSA GEMILANG JARINGAN PEDULI ANAK BANGSA, Teologi Anak (PT. Suluh Cendikia, n.d.).
}

baik. $^{3}$ Anak anak sendiri dapat di artikan sebagai pribadi yang masih kecil dan belum dewasa. Menurut Undang-Undang perlindungan anak pasal 1 yang di maksud anak adalah seorang yang belum berusia delapan belas tahun, termaasuk anak yang masih dalam kandungan. ${ }^{4}$ Anak adalah anugerah Tuhan yang mulia dan sangat berharga, dimana anak memiliki potensi yang sangat luar biasa sejak dari kecil dan anak adalah pemimpin. Oleh sebab itu perlu di kembangkan atau di bangun sejak kecil.

Dalam Alkitab kita bisa melihat seorang tokoh yang bernama Samuel, di mana Tuhan memilih dan menyiapkan Samuel sejak dari kecil menggantikan Imam Eli dalam kepemimpinannya. Anakanak adalah generasi penerus yang di siapkan Tuhan untuk menjadi pemimpin kedepan. Oleh sebab itu, sangat penting bagi orang dewasa atau orang tua membangun kepemimpinan dalam diri anak seperti Imam Eli yang mempersiapkan Samuel menggantikan kepemimpinannya. Anak dapat dibimbing dan diberikan arahan sejak dini bahwa anak layak jadi pemimpin dan mampu menunjukan kepemimpinannya seperti yang Tuhan nyatakan melalui Samuel. $^{5}$ Kita harus

\footnotetext{
${ }^{5}$ Yeni Elyanna, "Membangun Mental Kepemimpinan Anak Melalui Kecerdasan Linguistik" (2021).
} 
melihat anak itu luar biasa karena dia adalah orang yang sangat berharga di mata Tuhan. Anak itu memiliki kemampuan/potensi sejak dari kecil dan mereka adalah pemimpin, dan semua tergantung bagaimana cara orang tua membimbing dan mengarahkan mereka dan menanamkan nilai-nilai dalam diri mereka. Orang tua harus menjadi contoh dan teladan bagi mereka dan membimbing mereka sejak dari kecil. ${ }^{6}$ Keluarga yang menjadi tempat utama dalam membentuk jiwa kepemimpinan dalam diri anak-anak sejak dari kandungan. ${ }^{7}$

\section{METODE PENELITIAN}

Metode yang digunakan dalam penelitian ini adalah metode penelitian kepustakaan/literatur. Metode kepustakaan adalah metodek yang di gunakan dalam pengumpulan data yang berasal dari sumber-sumber kepustakaan berupa bukubuku, makalah, jurnal, majalah dan sumber lain yang dianggap perlu dan mendukung. Data yang terkumpul sesuai yang dianalisis kemudian di Tarik kesimpulan. Dalam kajian ini, sumbernya berupa sumber primer dan sekunder. ${ }^{8}$

Tujuan dari penelitian ini adalah defenisi kepemimpinan, nilai-nilai

\footnotetext{
${ }^{6}$ Julianto Simanjuntak, Mendidik Anak Utuh Menuai Keluarga Tangguh (Tangerang, 2020), hal 95.

${ }^{7}$ Asnita Berkati Harefa, "KESENJANGAN ORANG TUA DALAM MEMBANGUN SIKAP KEPEMIMPINAN ANAK," 2021.
}

kepemimpinan, cara membangun kepemimpinan dalam diri anak, orang tua dalam membangun kepemimpinan dalam diri anak sejak usia dini.

\section{PEMBAHASAN}

Kepemimpinan adalah pemimpin yang bertindak di dalam kelompok. Kepemimpinan adalah hubungan dalam mengembangkan tujuan Bersama berdasarkan perilaku pemimpin. Kepemimpinan adalah keefektifan kemampuan dalam memengaruhi seluruh pengikut untuk mencapai tujuan bersama. Kepemimpinan adalah perilaku memengaruhi pengikut untuk mencapai tujuan bersama. $^{9}$

Setiap manusia adalah pemimpin, minimal memimpin dirinya sendiri. Oleh sebab itu kepemimpinan adalah urusan setiap orang. Semua manusia adalah pemimpin termasuk anak-anak kecil. Anak-anak akan menjadi pemimpin atas dirinya sendiri itu semua tergantung bagaimana kepemimpinan yang dialaminya dari orang yang memimpinnya. Kepemimpinan seorang pemimpin akan berpengaruh pada pengikutnya. Kata leader pertama kali digunakan pada awal tahun 1300-an. Cowley (1920) menyatakan

\footnotetext{
${ }^{8}$ Mukodi Mukodi, "Tela'ah Filosofis Arti Pendidikan Dan Faktor-Faktor Pendidikan Dalam Ilmu Pendidikan," Jurnal Penelitian Pendidikan 10, no. 01 (2018).

${ }^{9}$ M.T. Prof.Dr. Husaini Usman, M.Pd., Kepemimpinan Efektif (Jakarta, 2019), hal, 12.
} 
bahwa pemimpin adalah orang yang berhasil mengumpulkan orang lain untuk mengikutnya. Bush (2008: 4) menyatakan bahwa pemimpin adalah orang yang menentukan tujuan, memotivasi dan menindak pengikutnya. Seorang pemimpin mampu meningkatkan taraf orang yang dipimpinnya dan bertanggung jawab pada orang yang dipimpin. Jadi, pemimpin adalah orang yang mampu memberikan pengaruh kepada orang lain dan membawa perubahan. ${ }^{10}$

kepemimpinan merepakan kecakapan seseorang untuk memberi pengaruh pada orang lain tanpa paksaan dan mampu menggerakkan, memotivasi, dan menjadi teladan, sehingga adanya perubahan untuk mencapai tujuan bersama.

\section{Nilai-nilai kepemimpinan}

Nilai-nilai dalam kepemimpinan merupakan sejumlah sifat-sifat utama yang harus dimiliki oleh seorang pemimpin supaya kepemimpinannya lebih efektif dan efesien untuk mencapai tujuan yang telah di tentukan. Nilai-nilai yang harus dikembangkan dalam kepemimpinan termasuk dalam diri anak dimulai sejak usia dini yaitu kejujuran, Kerjasama, kebaikan hati, kepedulian, dan ke disiplinan. ${ }^{11}$ Orang tua memiliki tanggung jawab besar dalam menanamkan nilai-nilai di atas dalam diri

\footnotetext{
10 Ibid., hal 1-3.
}

anak sejak dari kecil. Karena keluarga adalam tempat utama dan pertama anak untuk belajar. Dari nilai-nilai diatas yang utama adalah bagai mana orang tua mengajarkan anak nilai kebenaran kepada anak. "Ul 6:7 haruslah engkau mengajarkan berulang-ulang kepada anakanakmu dan membicarakannya apa bila engkau duduk dirumahmu, apabila engkau sedang dalam perjalanan, apabila engkau berbaring dan apabila engkau bangun." Artinya orang tua tidak hanya mendidik dengan mengasihi anak, orang tua perlu mendidik anak mengasihi Tuhan. Orang harus mendidik anak setiap saat. Dasar membangun kepemimpinan dalam diri anak adalah terlebih dahulu kita memperdilikan kesejahteraan rohani anakanak dan berusaha menuntun mereka kepada hubungan yang setia dengan Allah.

Membina rohani atau kepemimpinan dalam diri anak merupakan perhatian yang utama semua orang tua. Pengarahan harus berpusat dirumah, melibatkan ayah dan ibu. Dengan demikian juga orang tua harus menanamkan nilainilai yang baik kepada anak sejak kecil, dimanapun berada dan kapanpun waktunya. Artinya tidak ada batas waktu dalam mendidik anak, dan jangan bosan-bosan dalam mendidik anak-anak, supaya

\footnotetext{
${ }^{11}$ Dr. Dadan Suryana, Stimulasi Dan Aspek Perkembangan Anak (Jakarta, 2016).
} 
kepribadian mereka terbentuk dari kecil dan itu akan menjadi bekal bagi mereka untuk menjadi pemimpin yang berkualitas.

\section{Cara membangun kepemimpinan dalam} diri anak

Untuk membangun kepemimpinan dalam diri anak orang tua terlebih dahulu menjadi Role Model dalam mendisplinkan anak sejak dari kecil. John C. Maxwell mengatakan bahwa pemimpin penting memiliki disiplin pribadi agar memiliki daya focus dan bekerja mencapai tujuantujuannya. ${ }^{12}$ Tim Elmore mengungkapkan bahwa sangat untuk membangun kepemimpinan anak harus melatih anak disiplin dan bertanggung jawab sejak dari kecil, memberikan motivasi yang baik serta mendorong anak untuk menemukan tujuan/hasrat yang ingin anak lakukan ketika dewasa nanti. ${ }^{13}$

\section{Orang Tua Dalam Membangun} Kepemimpinan Dalam Diri Anak Sejak Usia Dini

Dengan semakin berkembangnnya zaman banyak orang tua yang gagal dalam memberikan pola asuh yang baik pada anak. Bahkan banyak orang tua yang tidak sadar akan tanggung jawabnya terhadap anak, banyak orang tua mengharapkan

\footnotetext{
12 John C. Maxwell, The 5 Leves of Leadership.

${ }^{13}$ Elmore and John C. Maxwell, Mengembangkan Talenta Kepemimpinan Dalam Anak Anda, hal, 7273.
}

anaknya berhasil kedepan, tapi mereka tidak tau cara mengasuh dan membimbing anak. sehingga anak banyak mengalami kegagalan dan tidak memiliki keberanian untuk bangkit jika sudah berajak dewasa karena tidak memberikan pola asuh yang baik waktu kecil.

Kalau kita memakai kacamata sebuah "organisasi” maka peran orang tua dapat juga dianalogikan sebagai seorang atasan dalam sebuah keluarga dan anakanak merupakan bawahannya. Namun dalam memimpin organisasi sangat berbeda dengan keluarga. Tugas orang tua adalah memikirkan dan melakukan cara-cara seperti apa yang memang sesuai dengan kondisi anak. bukan sekedar memerankan peran sebagai orang tua dengan orientasi ingin menjadikan anak sebagai moniatur orang tua. sehingga tidak membuka ruang bagi anak untuk mengekspresikan kebebasannya dan hak-hak yang dimiliki anak. $^{14}$

Kepemimpinan dalam sebuah oraganisasi adalah pemimpin harus memastikan anggota atau pengikutnya memiliki visi atau tujuan dan memahami kontribusi apa yang hendak dilakukan dalam mencapai tujuan itu. ${ }^{15}$ Orang tua juga

\footnotetext{
${ }^{14}$ E. Widijo Hari Murdoko, Parenting with Leadership (Jakarta, 2017).

${ }^{15}$ Ahmad Tabrani, "PENGARUH KEPEMIMPINAN DAN MENTORING TERHADAP MOTIVASI DALAM
} 
mempunyai tugas sebagai pemimpin bagi anak-anak untuk membangun kepemimpinan dalam diri anak, sehingga anak-anak bisa mengenal visi dan tujuan hidup anak dan kelak anak akan menjadi pemimpin yang luar biasa.

Orang tua berperan dalam membangun kepemimpinan pada anak sejak dini

Untuk membenagun kepemimpinan dalam diri anak sejak dini orang tua harus:

\section{Memberi Rasa Aman}

Memberikan rasa aman kepada anak. Memberikan rasa aman dan percaya pada anak. orang tua harus memahami anak sejak dari kecil dan menciptakan rasa aman dalam keluarga. Karena anak brtanggapan bahwa dunia yang di tempatinya adalah dunia yang aman, menakutkan, mencintai atau membencinya tergantung bagai mana orang tua menciptakan rasa aman pada anak sejak kecil. Anak-anak berhak menjadi orang yang berguna, dan untuk mencapai semua itu tergantung dari Pendidikan yang diterima anak. ${ }^{16}$

\section{Karakter}

Karakter merupakan hal yang sangat penting, ini dapat kita ketahui dalam

MELAYANI," EDULEAD: Journal of Christian Education and Leadership 1, no. 1 (June 9, 2020): 77-91, http://stak-pesat.ac.id/ejournal/index.php/edulead/article/view/23. ${ }^{16}$ Harefa, "KESENJANGAN ORANG TUA DALAM MEMBANGUN SIKAP KEPEMIMPINAN ANAK." pembukaan UUD 1945 mengatakan kata aklhak mulia. Karakter adalah kepribadian atau watak yang dapat membedakan seseorang dengan orang lain. Dalam hal mendekripsikan bahwa karakter merupakan nilai, sikap yang sudah dimiliki atau yang akan di tanamkan kepada seseorang sejak dari dini. Dalam hal ini orang tua merupakan factor utama yang mempengaruhi karakter anak. karakter yang orang tua tanamkan dalam diri anak salah satunya adalah "kejujuran". Kejujuran ini merupakan hal yang di kembangkan dimulai oleh orang tua di rumah. Cara mengajarkan anak nilai jujuran yaitu orang tua memberikan pemahaman kepada anak penting bersikap jujur dan orang tua menjadi teladan. Misalnya, orang tua sudah terlanjut berbohong kepada anak meskipun itu hal kecil tetapi orang tua harus meminta maaf kepada anak. Dengan begitu anak bisa belajar dan meniru apa yang di lakukan oleh orang tua. ${ }^{17}$

Dan dalam membangun kepemimpinan dalam diri anak pun orang tua mengajarkan hal yang sama. Orang tua memberikan pemahaman kepada anak tentang kepemimpinan dan memberikan dorongan kepada anak sejak dari kecil yang

\footnotetext{
17 Santosa Santosa and Guntur Firman Aprianto, "Implementasi Penginjilan Dan Pemuridan Dalam Pengembangan Karakter Jujur Anak Usia 9-10 Tahun," JURNAL TEOLOGI GRACIA DEO 2, no. 2 (2020): 94-108.
} 
berupa pertanyaan-pertanyaan yang membuat anak berpikir dan mengerti kepemimpinan itu seperti apa sehingga adanya Hasrat dalam diri anak untuk menjadi pemimpin.

Jadi, anak tidak hanya memiliki karakter yang baik tetapi anak dalam hal ini juga memiliki potensi atau kemampuan untuk menjadi seorang pemimpin, dan supaya mereka menjadi pemimpin yang yang efektif orang tua perlu membimbing, mengarahkan, mendidik dan mendorong mereka sejak dari kecil.

\section{Kebutuhan Anak Yang Harus Dipenuhi Orang Tua}

Kebutuhan Fisik

Kebutuhan fisik ini disebut juga dengan kebutuhan asuh. Dimana orang tua memberikan perawatan Kesehatan, nutrisi yang baik, pakaian, rumah dan sanitasi lingkungan. Ini akan berpengaruh dalam pertumbuhan anak semua yang yang berkaitan dengan kegiatan fisik. Orang tua harus memperhatikan hal ini supaya anak terus bertumbuh dan berkembang sesuai harapan.

\section{Kebutuhan Pendidikan}

Pendidikan juga sebagai kebutuhan anak. Orang tua sangat penting untuk berperan sebagai guru utama bagi anak- anak. Bukan hanya semata masalah intelektual, tetapi pendidikan pembentukan kepribadian yang luhur. Termasuk dalam Pendidikan, agama, moral, psikis, social. Orang tua yang selalu melakukan dengan sederhana dirumah.

\section{Emosi}

Kebutuhan emosi ini merupakan kebutuhan anak sejak dari kandungan. Anak selalu memerlukan ikatan yang erat dan serasi dengan ibunya dengan mmenjamin tumbuh kembangnya. Orang tua memberikan kasih sayang, merasa dilindungi, harga diri, perhatikan minat, keinginan dan pendapatnya, mandiri, diberi contoh (bukan dipaksa), sukses, doronga, motivasi, bantuan, penghargaan, mendapatkan kesempatan dan pengalaman, didikan dengan penuh kegembiraan, melakukan koleksi dengan kasih sayang bukan ancaman tau hukuman.

\section{Kebutuhan stimulasi}

Kebutuhan stimulasi bisa disebut dengan kebutuhan asah. Kebutuhan ini merupakan awal proses pembelajaran pada anak. Stimulasi adalah orang tua memberikan rangsangan kepada anak 
dengan segala hal. Rangsangan akan meberikan pengetahuan baru pada anak. ${ }^{18}$

\section{Pentingnya Membangun Kepemimpinan} dalam Diri Anak

Membangun kepemimpinan dalan diri anak sejak usia dini merupakan hal yang sangat penting. Di dalam kepemimpinan sangat dibutuhkan adanya dorongan dan motivasi dan membuat karakter muncul sejak usia dini, supaya anak punya kepercayaan diri dan dapat di percayai oleh orang lain.

Kepercayaan diri merupakan suatu keyakinan yang dimiliki seseorang bahwa dirinya mampu berperilaku seperti yang dibutuhkan untuk memperoleh hasil seperti yang di harapkan (Bandura, 1977). Luster (1978) mengungkapkan ciri-ciri orang yang percaya diri adalah mandiri, tidak mementingkan diri sendiri, cukup toleran, ambisius, optimis, tidak pemalu, yakni dengan pendapatnya sendiri dan tidak berlebihan. ${ }^{19}$ Dalam membangun kepemimpina dalam diri anak sejak usia dini sangat penting terlebih dahulu menumbuhkan kepercayaan diri anak.

\section{DAFTAR PUSTAKA}

Dewi Iriani. 101 Kesalahan Dalam

\footnotetext{
18 Dewi Iriani, 101 Kesalahan Dalam Mendidik Anak (Jakarta, 2014).

${ }^{19}$ Muzdalifah M Rahman, “Peran Orang Tua Dalam Membangun Kepercayaan Diri Pada Anak Usia
}

\section{KESIMPULAN}

Kepemimpinan adalah perubahan yang menuju pada kebaikan. Semua manusia bisa menjadi pemimpin, termasuk anak usia dini. Anak-anak adalah pribadi yang unik dan sangat berharga dimata Tuhan dan setiap anak memiliki bakat, dan potensi yang berbeda-beda. Orang tua sangat berperang penting dalam membentuk kepemimpinan dalam diri anak yang dilatih sejak mereka kecil. Dalam membangun kepemimpinan anak orang tua harus memberikan rasa aman dan kasih sayang penuh dan membentuk karakter anak sejak dari mereka kecil. Dengan penganalisa yang dilakukan, pola asuh orang tua sangat kuat dalam memberikan pengaruh pada anak. begitu juga dengan anak kelak akan memberikan pengaruh yang sangat luar biasa. Membangun kepemimpinan anak sangat penting untuk diperhatikan oleh orang tua, sehingga anak menjadi pribadi yang lebih baik kedepannya.

Mendidik Anak. Jakarta, 2014.

Dr. Dadan Suryana. Stimulasi Dan Aspek

Dini," Edukasia: Jurnal Penelitian Pendidikan Islam 8 , no. 2 (2013). 
Perkembangan Anak. Jakarta, 2016.

E. Widijo Hari Murdoko. Parenting with Leadership. Jakarta, 2017.

Elmore, Dr. Tim, and John C. Maxwell.

Mengembangkan Talenta

Kepemimpinan Dalam Anak Anda.

Jakarta, 2002.

Elyanna, Yeni. "Membangun Mental

Kepemimpinan Anak Melalui

Kecerdasan Linguistik” (2021).

Harefa, Asnita Berkati. "KESENJANGAN

ORANG TUA DALAM

MEMBANGUN SIKAP

KEPEMIMPINAN ANAK," 2021.

John C. Maxwell. The 5 Leves of

Leadership. surabaya, 2017.

Julianto Simanjuntak. Mendidik Anak Utuh

Menuai Keluarga Tangguh.

Tangerang, 2020.

Mukodi, Mukodi. “Tela'ah Filosofis Arti

Pendidikan Dan Faktor-Faktor

Pendidikan Dalam Ilmu Pendidikan."

Jurnal Penelitian Pendidikan 10, no.

01 (2018).

Prof.Dr. Husaini Usman, M.Pd., M.T.

Kepemimpinan Efektif. Jakarta, 2019.
Rahman, Muzdalifah M. "Peran Orang Tua Dalam Membangun Kepercayaan Diri Pada Anak Usia Dini."

Edukasia: Jurnal Penelitian

Pendidikan Islam 8, no. 2 (2013).

Santosa, Santosa, and Guntur Firman Aprianto. "Implementasi Penginjilan

Dan Pemuridan Dalam

Pengembangan Karakter Jujur Anak

Usia 9-10 Tahun." JURNAL

TEOLOGI GRACIA DEO 2, no. 2

(2020): 94-108.

Tabrani, Ahmad. "PENGARUH

KEPEMIMPINAN DAN

MENTORING TERHADAP

MOTIVASI DALAM MELAYANI."

EDULEAD: Journal of Christian

Education and Leadership 1, no. 1

(June 9, 2020): 77-91. http://stak-

pesat.ac.id/e-

journal/index.php/edulead/article/vie

$\mathrm{w} / 23$.

TIM ANAK BERSINAR BANGSA

GEMILANG JARINGAN PEDULI

ANAK BANGSA. Teologi Anak. PT.

Suluh Cendikia, n.d. 